\section{YSM \& OSM epilog}

PAGES 1st Young Scientists Meeting and 3rd Open Science Meeting were held in July in Corvallis, Oregon, USA (see p. 131134 this issue). There was a great deal of interaction and networking, and we would like to thank everyone who participated. We received very positive feedback for both meetings and a lot of very useful input on PAGES science activities and future plans. An online poster exhibition has been set up for both meetings and videos of the entire OSM program can be viewed online (http://www.pages-osm.org/osm/ videos.html). The videos are available to order gratis in DVD form from PAGES online Product Database (http://www.pagesigbp.org/products/). The inaugural meeting of the PAGES Last 2 Millennia Theme, including representatives from each of the current Working Groups-Africa, Antarctic, Arctic, Australasia, Asia Europe, North and South America-was also held in Corvallis (see p. 130 this issue).

PAGES will hold its next YSM and OSM in 2013. The location is still to be determined. Details will be posted online (http://www.pages-osm.org/) as they become available.

\section{SSC and EXCOM meetings}

PAGES Scientific Steering Committee (SSC) and Executive Committee (EXCOM) met in Troutdale, Oregon after the OSM. Discussion items included general business, budgets for the next financial year and the upcoming grant for funding of the PAGES project for 2010-2013, which is due to the Swiss and US National Science Foundations at this end of this year. Minutes from the meetings will soon be available online (http://www.pages-igbp.org/people/ sscmembers/meetingminutes.html). SSC members also elected new SSC members for 2010. The new members will be announced in the next issue. In addition, the
SSC and EXCOM evaluated proposals for new PAGES Working Groups and applications for workshop funding (see below).

\section{New Working Groups}

The SSC and EXCOM approved two new proposals for PAGES Working Groups, one on Varves (under Cross-Cutting Theme 1: Chronology) and another on the Marine Nitrogen Cycle (under the "Paleoperspectives on Ocean Biogeochemistry" Theme of PAGES Focus 3: Global Earth-System Dynamics). To get involved, contact Pierre Francus (pfrancus@ete.inrs.ca) and Markus Kienast (markus.kienast@dal.ca), respectively. Information on these and other Working Groups, or on how to propose a new Working Group within PAGES can be found online (http://www.pages-igbp. org/science/workinggroups.html).

\section{Workshop Support}

Three proposals to the Open Call for Workshop Support in May were awarded financial support. The newly formed Varve WG was allocated funding for its first workshop, planned for the end of 2009/ beginning of 2010 in Estonia. The two other supported meetings, both INQUA activities, were a West African Quaternary workshop on paleoclimatic sea level changes and anthropogenic responses (Nigeria, 26-30 October 2009), and a workshop on tephrochronology, volcanism and human activity (Japan, 10-17 May 2010). Details are in PAGES online calendar of paleo-events (http://www.pagesigbp.org/calendar/). The next Open Call deadline is Sunday, 15 November 2009. Application guidelines can be found online (http://www.pages-igbp.org/resourc es/support/guidelines.html).

\section{Hot off the Press}

PAGES new Science Plan and Implementation Strategy, the third in PAGES 18-year history, was recently published. It aims to galvanize the paleocommunity towards answering the key questions of the coming decade. These questions are directed at developing a better understanding of climate-environment sensitivity, regional variability, global system behavior and human interaction with climate and environment. It is available in digital form and hardcopy. Another strategic document that is now available for download is the revised Vision Document of the PAGES/ CLIVAR Intersection Panel that outlines the framework of topics to be tackled by the Panel in the coming years. Other recent PAGES publications are the Palaeogeography, Palaeoclimatology, Palaeoecology special issue (281:3-4, 175-376) on "Long-term multi-proxy climate reconstructions and dynamics in South America (LOTRED-SA): State of the art and perspectives", (conference proceedings from the LOTRED-SA workshop held in October 2006 in Argentina), and a paper in Nature Geoscience (doi:10.1038/ngeo660), "Interglacial diversity", resulting from the first PIGS (Past Interglacials) Working Group meeting held in October 2008 in France. Further details and/or downloads of above products are available through PAGES online Product Database at http://www.pages-igbp.org/ products/

\section{Next issue of PAGES News}

The first issue for 2010 will contain a special section on peatland paleoscience, guest edited by Stephen Jackson and Dan Charman. The deadline for contributions to this special section as well as to the open section, unrelated to the peatland topic, is 11 January 2010. Guidelines for contributions can be found online (http:// www.pages-igbp.org/products/newsletters/instructions.html).

\section{2}

\title{
Eulogy: John "Jack" Eddy
}

Raymond S. Bradley

Department of Geosciences, University of Massachusetts, USA; rbradley@geo.umass.edu

Sadly, one of the guiding lights and strongest supporters of PAGES passed away on 10 June 2009. John A. Eddy, known to all his friends as Jack, played a key role in promoting the concept of interdisciplinary research and the important perspective that studies of past climate changes could bring to Earth System science.

As Director of the Office of Interdisciplinary Earth Studies within the Univer- sity Corporation for Atmospheric Research (UCAR) in Boulder, Colorado, Jack became an influential and eloquent spokesman for the kinds of interdisciplinary research that we take for granted nowadays. But in the 1980s, the concept was a hard sell; breaking down the walls that separated the traditional disciplines was difficult. Jack never wavered in his ardent belief that a more holistic view of the Earth was essential, and he used his considerable persuasive talents and his reputation as an eminent astrophysicist to promote this agenda. One of the most important steps in this process was the "Global Change Institute" that he organized in the summer of 1989, in Snowmass, Colorado. This brought together many of the leaders in paleoclimatology from around the world to work together for 2 weeks, challeng- 
ing each other's ideas and developing the plans that later became the foundation of the PAGES scientific strategy (Bradley and Eddy, 1991). At the same time, the Science Advisory Council for IGBP committed to, "a major new international research project dealing with ... a coordinated effort to recover information from natural archives that will illuminate connections between atmospheric composition, global temperature, ice extent, solar history, and the distribution of land and oceanic organisms".

This meshed perfectly with Jack's vision of what was needed, and in 1991 the first meeting of the PAGES Scientific Steering Committee was held in Mainz. I fondly remember Jack leading a critical discussion-what should the new project be called? There was already a potential acronym-"PaGloCha" (Past Global Changes) but this hardly seemed to have the same catchiness and imagery that "PAGES" had. After all, wasn't the plan to use natural archives to look back in time, as one might flip back through the pages of a book? Jack was his usual persuasive self, and the new name was readily adopted. He then played a critical role in obtaining a commitment from the U.S. National Science Foundation to team up with the Swiss Science Foundation and co-fund a coordination office in Bern.

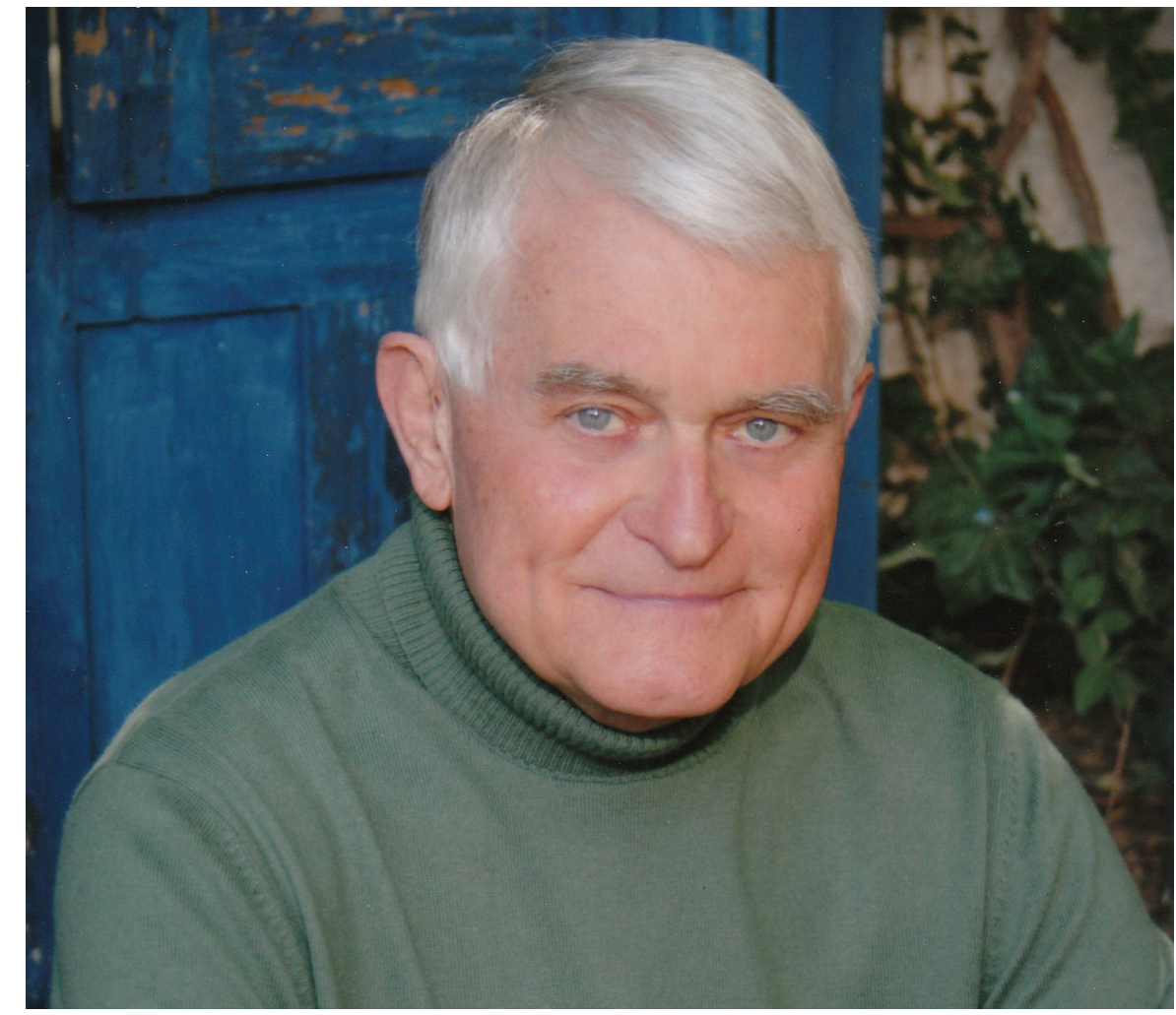

"Jack" Eddy, photographed by Barbara Eddy

The PAGES community has greatly benefited over the years from Jack's relentless and enthusiastic support for the project in its formative years. These are simple facts that document his role. But those who knew Jack will remember him first and foremost as one of the warmest and most sincere individuals you could ever hope to meet.

\section{References}

Bradley, R.S. and Eddy, J.A., 1991: Records of past global changes. In: R.S. Bradley (Ed), Global Changes of the Past, University Corporation for Atmospheric Research, Boulder, p. 5-9.

\section{PAGES Calendar 2010}

15 - 19 Feb 2010 - Bariloche, Argentina VI Southern Connection Congress - Gondwana reunited: A southern perspective for a changing world

http://www.sccongress2010.com.ar/

10 - 17 May 2010 - Kyushu Island, Japan

(S) International field conference and workshop on tephrochronology, volcanism and human activity http://www.ris.ac.jp/intav-jp/
10 - 13 May 2010 - Edinburgh, UK AIMES Open Science Conference "Earth system science: Climate, global change and people" http://www.pages-igbp.org/calendar/

\section{Aug - 3 Sep 2010 - California, USA $10^{\text {th }}$ International Conference on Paleoceanography http://icp10.ucsd.edu/}

13 - 15 Sep 2010 - Shanghai, China (2) $2^{\text {nd }}$ PAGES Global Monsoon Symposium http://www.pages-igbp.org/calendar/

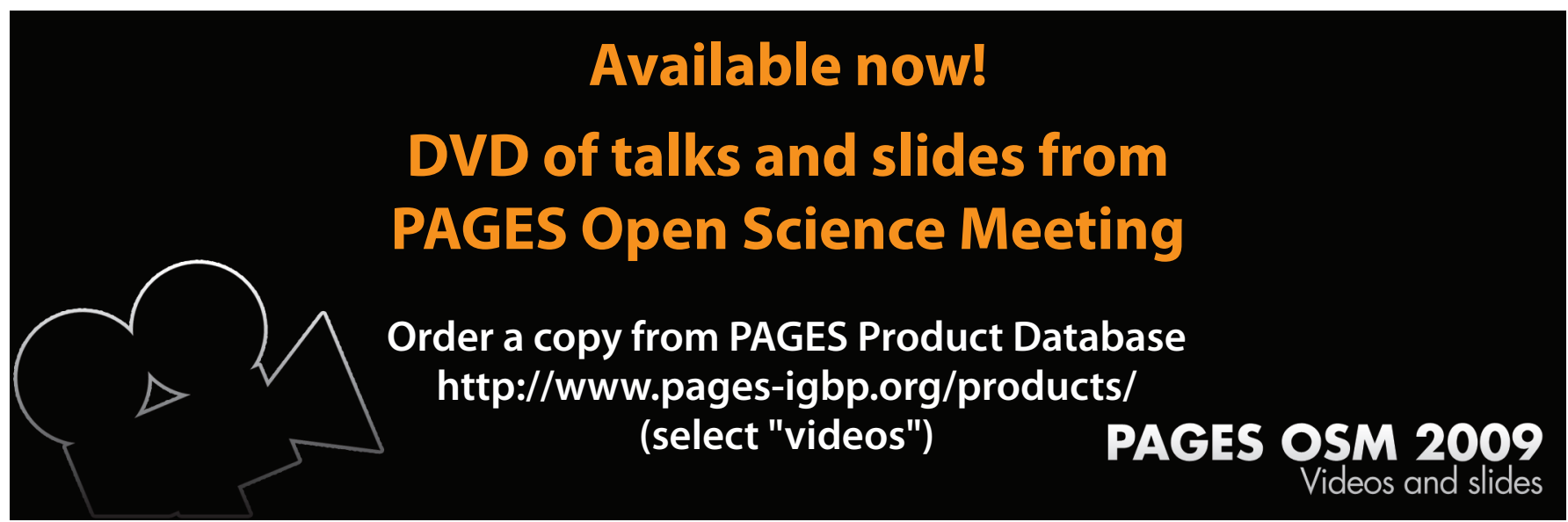

